\title{
1. Money endogeneity before central banking: perspectives from monetary history
}

\section{Jane Knodell}

\section{INTRODUCTION}

This chapter contributes an economic historian's perspective to the debate among post-Keynesian theorists about the endogeneity of money before the development of modern monetary institutions. I bring historical and institutional evidence from the metallic money systems of early-modern western Europe and the paper-money systems of eighteenth-century Great Britain and British North America to bear on the debate. Monetary systems that did not have central banks still had supply mechanisms that allowed money to endogenously respond to demand, but these were not as effective as the supply mechanisms that characterize modern monetary systems. ${ }^{1}$

I start with a review of the debate among post-Keynesian economists, contrasting the views of the 'evolutionary' and 'revolutionary' positions on money endogeneity. While the 'evolutionary' position holds that money only became endogenous once fully modern monetary institutions, especially central banks, were in place, the 'revolutionary' position takes the strong position that money was endogenous with or without central banks, even in the early, metallic-money stage of monetary history. In this chapter I focus on the pre-central-banking period of monetary history, and ask: before we had central banks creating bank reserves more or less on demand, what were the supply-side mechanisms in monetary systems, and how well did they work in accommodating demand? Subsequent sections report on insights from the literature on the metallic-money systems of Medieval and Renaissance western Europe and the paper-money systems of Great Britain and the North American colonies before central banking. The last section concludes. 


\section{THE POST-KEYNESIAN DEBATE ON MONEY ENDOGENEITY AND INSTITUTIONS}

This section summarizes the two poles of the debate about the role of modern monetary institutions in creating the necessary conditions for money to be endogenous. Chick (1986) is taken to be the standard bearer for the 'evolutionary' position, and Rochon and Rossi (2013) represent the 'revolutionary' side of the debate. Rochon and Rossi offer a deep critique of the 'evolutionary' position in arguing that with or without modern monetary institutions, money has always been endogenous - even coined money. Their position leads a historian to ask: exactly how was money made endogenous before the emergence of central banks and large banking firms?

\section{The 'Evolutionary' Position}

In the debate about the role of institutional development in creating endogeneity, Chick (1986) characterizes the relationship between bank reserves, bank loans and bank deposits in different stylized stages in the evolution of modern banking systems. As the banking system evolves, there is a progression from deposit-led to reserve-led, and finally to loanled money-supply growth. In the early stages, banks are passive players; as the system evolves, they become active initiators of monetary expansion. At some point along the way, economic growth switches from a saving-led to an investment-led process.

Chick's (1986) stylized story is modelled roughly after the English experience. In Stage 1, '[b]anks are numerous and small, and geographically semi-isolated. Bank liabilities are not widely used as means of payment' (ibid., p. 113). As a result, banks could not lend until they received deposits of high-powered money, which could be 'regarded as exogenous to the banks' (ibid.). Economic growth was saving-led, and monetary growth was driven by deposits of high-powered money in banks. An implication of her presentation is that in Stage 1 money is 'exogenous' in the sense that it is not determined by the level of nominal income. ${ }^{2}$

In Stage 2, there is greater public confidence in banks, which are on average larger than in Stage 1. Clearing arrangements between banks have improved and some payments are cleared within multi-branch banking firms. Bank liabilities are now used as means of payment, which is crucial in terms of the banking system's ability to retain reserves as it expands lending. In Stage 2, the supply of money has been freed from the constraint previously created by the degree of substitutability in demand between bank liabilities and high-powered money, but money growth is 
still deposit-led and constrained by the stock of reserves. Money is not yet endogenous in the sense of being determined by the level of nominal income, but from this point forward investment can take place prior to saving.

In Stages 3 and 4, central-bank liabilities are used as high-powered money, and central banks accept full responsibility for the stability of the financial system. Central banks remove the constraint of reserves on loans and deposit creation. Once money growth is driven by loan demand (Stage 3), and the supply of credit money is always validated by a central banking institution, money becomes endogenously determined by the level of nominal income. ${ }^{3}$ In Chick's (1986) construction, then, money endogeneity requires two institutional developments: first, the growth of the size of banking firms to a scale large enough to earn the confidence of the non-bank public; second, the adoption of central-bank liabilities as high-powered money.

\section{The 'Revolutionary' Position}

On the 'revolutionary' side of the debate, associated with the accommodationist strand of post-Keynesian monetary economics, Rochon and Rossi (2013) argue that money is endogenous by its very nature. For an individual transaction to be carried out, means of payment must be made available and expressed in the appropriate sum of value; and this money must be issued by a 'third party' other than the parties to the transaction. ${ }^{4}$ Insofar as buyers (other than the king or the State) are not 'endowed with a seigniorage privilege', the conduct of trade creates a need for a 'means of final payment that has to be provided by a third party on the agents' demand' (ibid., p. 224, italics added). Since 'any payment is elicited by the "needs of trade", it follows that the money-creation process is always and everywhere endogenous - even if a central bank is non-existent or nonaccommodating with respect to the banks' demand for reserves' (ibid.). For Graziani (1990, p.11, italics in the original), money 'only comes into existence the moment a payment is made'.

In the view of Rochon and Rossi (2013), the form of money has changed many times over the course of history, but its intrinsic nature has not. Commodity money is every bit as endogenous as bank deposits when we examine its social purpose as a third-party means of payment and the way in which it is emitted into the economy. It is only in the specific historical case of a modern economy that money is introduced into the economy through the lending and production activities of banks and firms. To make the point that the endogeneity of money does not depend on the presence of modern monetary institutions, Rochon and Rossi (ibid.) seek 
to demonstrate that endogeneity holds even when a payment is carried out without money (as with early 'accounting banks'), or with 'primitive' forms of money such as goldsmith certificates. However, each of these stylized examples of 'third party' issuers of monetary instruments are essentially the same as the modern banks in Chick's (1986) Stage 3.

The debate sharpens on the question of the endogeneity of money coined from precious metals, because such money is not issued by a bank, or by a premodern bank-like organization.

Rochon and Rossi (2013, p. 223) maintain that even 'if the payment ... were carried out with a number of gold coins, instead of via the payment services provided by a bank or goldsmith, the analysis would not change as far as the endogenous nature of money is concerned'. Graziani (2003, p.61) puts it this way:

Money, not being a commodity, is in the nature of credit. However, it is not a direct credit between the two contracting agents, but an indirect relationship set up by means of a triangular transaction in which a third agent acts as an intermediary. Coined metal money, while having the appearance of a commodity money, is also in the nature of credit money.

Using a more 'evolutionary' approach to the issue, Eichner (1991, pp. 808-10) posited that the supply of coined money was not endogenous in the sense of being demand-determined. For Eichner (ibid.), the problem was metallic money's commodity character: when the precious metals' value as a commodity was higher than its value as money, it would not be taken to the mint - regardless of the state of money-demand conditions.

Within the Rochon and Rossi (2013) conceptual framework, it may be consistent to say that coined money is the same as bank money in that it only comes into existence at the moment that payment is made - that it is only demanded as a means of payment when it is meeting some 'needs of trade'. ${ }^{5}$ However, it does not follow that all of the means of payment needed to carry out potential or desired transactions will be supplied, or that commodity-price deflations will never occur because of an inadequate supply of coined money. This question of the adequacy of the supply of money is empirical. What were the institutional mechanisms of the supplyside response to money demand in metallic-money systems, and how well did they work?

The Rochon-Rossi view that money was endogeneous even before there were central banks is an intriguing one for a monetary historian. I follow their lead in what follows as I interpret the historical experience with metallic money through the endogenous-money lens. Before proceeding, it is useful to be clear about the definition of money. 


\section{Money and the Standard Asset}

Let us follow Chick's (1986) lead by drawing a distinction between 'money' broadly defined as all assets that are generally and widely accepted means of payment, and the one asset, variously termed the 'standard asset', 'outside money', or 'high-powered money', which is regarded as the ultimate and 'best' form of settlement. This is a useful distinction, because monetary systems are invariably characterized by a hierarchy of money forms, with assets on each 'rung' convertible or payable into assets on the rung above, with the 'standard asset' at the top of the pyramid. Given this chain of convertibility (or payability), the conditions governing the supply of the standard asset bear importantly on the endogeneity of money in different kinds of monetary systems.

In this regard, Smithin (2003, pp. 31-2) has contrasted systems in which the standard asset is in 'exogenously fixed supply' with those in which 'the ultimate asset consists simply of the liabilities of state-owned central banks, and which expands or contracts whenever the central bank makes advances or purchases investments' ${ }^{6}$ As Rochon and Rossi (2013) might point out, it is hard to see how any standard asset could be in exogenously fixed supply, since, as a social form, the standard asset - regardless of its physical form - is subject to social control and manipulation. As I show below in my discussion of the monetary history literature, Smithin (2003) overstates the exogeneity of coined money. Conceptually, however, Smithin (2003) has identified the key institutional feature that determines whether or not, in a given monetary system, the supply of means of payment can constrain the level of economic activity.

\section{THE METALLIC-MONEY SYSTEMS OF MEDIEVAL AND RENAISSANCE WESTERN EUROPE}

It would be a mistake to characterize early modern economies as hamstrung by fixed stocks of metallic money. Over the long run, the opening of new mines and mints increased the capacity to produce coined money; the metallic content in the money supply, valued in terms of local units of account, fell; and trading communities developed substitutes for large coins. Even so, metallic coin was the standard asset, and there were persistent problems with securing an adequate supply. 


\section{The Supply of Coin}

The money supply consisted of small and large metallic coins and some forms of inside money (discussed below). Small coin was made from alloys of the cheapest metal and used for small retail transactions within a local economy; large silver or gold coin was used for larger, regional domestic transactions between cities, between city and country, and for international payments. Both small and large coins were used as monies of account, means of payment (although these two functions were not always unified in the same coin in a given locale), and standard asset in their respective spheres of circulation.

Coined money was issued in exchange for precious metals; mints did not monetize debt the way banks do. ${ }^{7}$ The supply of coin depended on factors governing the supply of precious metal at mines and the conversion of mintable metal into coin at mints. The monetary history literature provides considerable support for Eichner's (1991) view that the economics of mining and minting could cause the supply of coined money to fall short of demand in the aggregate.

Coins were produced by mints operating under the authority of king or parliament. Ordinances defined the mint price and the seigniorage tax. The mint price was the rate at which mints were to convert a given quantity and fineness of metal presented by the 'non-mint public' into coin representing so many units of account. Mints were authorized to actually produce an amount of coined money slightly greater than the mint price, the 'mint equivalent'. The difference between the mint equivalent and the mint price was the gross seigniorage 'wedge', which covered minting costs, seigniorage tax, and any profit for the mintmaster. ${ }^{8}$

Mint prices can be decomposed into the 'intrinsic' and 'extrinsic' value of coin, both of which were set by the monetary authority. 'Intrinsic' value was the amount of metal a certain type of coin was to contain, defined in terms of type, weight and quality. The 'extrinsic' or 'tariff' value was the number of units of account represented by a coin of a certain type, as determined by officially established tariffs (Fantacci, 2005, pp. 46-7). ${ }^{9}$ This distinction is useful because coins were stamped without denominations, allowing the authorities to change the 'face value' of coin without reminting it, by changing the tariff value.

The main clients of the mints were merchants, both as suppliers of mintable metal and users of coined metal. This was a 'market driven' system of coinage in the sense that mints were required to convert all the metal presented into coin at the posted mint prices (see Spufford, 1970, p. 54; Redish, 2000, p.27). As proponents of endogenous money would expect, broadly speaking there was a connection, across time and space, 
between levels of economic activity and mining output. But the level of coined money could deviate sharply from that needed to circulate goods and services because of two structural problems: long response times in the supply of mintable metals, and the intrinsic difficulty of setting mint prices to get the right quantities of coined money.

In theory, the supply of mintable metals was demand-driven: economic expansion (contraction) would increase (decrease) the demand for mintable metals, causing their value to rise (fall) and mining output to rise (fall). One of the leading historians of Medieval monetary systems, Cipolla (1963, pp. 417-18), claimed that the supply of precious metals 'did not expand proportionately to the demand for money', suggesting that, at best, the supply response was slow. ${ }^{10}$ Perhaps the best historical example of an inelastic supply of precious metals was the 'bullion famine' of the late fourteenth and fifteenth centuries, during which silver mines in central Europe were depleted, stocks of silver were exported to the Far East, and remaining stocks of silver tended to be hoarded. Historians have debated whether the decline in output of mintable metals was a cause or effect of economic stagnation. ${ }^{11}$ Regardless of the direction of causality, it is incontrovertible that the response of the supply of precious metals to changes in demand was in this instance very slow: the bullion famine of the late fourteenth century was alleviated with a 100-year time lag, by the opening of new sources of silver in the Americas in the sixteenth century.

As regards the conversion of mintable metal into coined metal, the mismanagement of metallic money caused the supply of coin to diverge from demand in the short and medium run. Metallic money was difficult to manage in the sense that it was hard to get all the relative prices right. There were several ways that relative prices could be wrong, particularly in a politically fragmented bimetallic system such as western Europe's between the thirteenth and seventeenth centuries. These problems were all founded in the dual nature of metallic money as both a means of payment and commodity traded on world markets.

The first problem was that when the precious metal was worth more as metal than as coin, coin would be melted down, causing the money stock to fall. ${ }^{12}$ In a world with large and small coin, there could also be shortages of one denomination of coin or the other. Mint prices were generally the same, per unit-of-account value, for large and small coin, but it cost about the same to produce a small coin as a large one, so that mintmasters received larger profits on large coin than on small (Spufford, 1970, p. 44). Sargent and Velde's (2002, p. 28) work shows why, given the difference in per-unit production costs, it was 'difficult to avoid misalignments' of mint prices and mint equivalents for the two coins that would cause one or the other coin to disappear from circulation. This is not just a hypothetical 
possibility created by modern theory; there is extensive historical evidence from Medieval England, France and Italy of a recurrent shortage of small coin (Redish, 2000, ch. 4; Sargent and Velde, 2002, ch. 8). ${ }^{13}$

Management of the coinage (as regards mint prices, debasements and recoinages) was uncoordinated across political entities. There were as many local monies of account, circulating at varying degrees of debasement, as there were political authorities. If mint prices in one country were sufficiently lower than mint prices in another, metal would be exported, and the money supply would shrink. Similarly, if their domestic mint prices undervalued a precious metal in relation to its market price, metal would be sold and the money supply would shrink. To protect their domestic money supplies, individual monetary authorities had to keep their domestic mint prices aligned with foreign mint prices and with market prices for the precious metals used in their domestic stock of coin. Inevitably, adjustments in domestic mint ratios lagged behind changes in foreign ratios and supply-driven changes in market prices. Consequently, the stock of precious metals was constantly being moved around between localities in a manner totally disconnected from shifts in local demand. ${ }^{14}$

England's commercial crisis of the early 1620s is an example of the monetary problems created when the authorities failed to align mint prices with market prices. In response to the inflow of American silver in the sixteenth century, silver tended to depreciate against gold, requiring authorities to adjust their minting ratios to protect their stocks of gold. The English authorities persistently set the mint price of gold too high, overvaluing gold (undervaluing silver), resulting in an outflow of silver and an inflow of gold bullion. Gold and silver were not perfect substitutes as means of exchange: gold was relatively useless in domestic circulation because of its high value in terms of the unit of account. The result was a painful deflation in domestic incomes and prices; economic transactions 'almost ceased' because of the lack of a circulating medium (Supple, 1957, p. 245).

Notwithstanding the various ways in which the supply of metallic money could become disconnected from demand in the short and medium run, there were long-run supply mechanisms, unique to pre-gold-standard metallic money systems, that created a degree of freedom between the size of the money supply and the physical and economic conditions of mining and minting metal. Throughout western Europe, the metallic content in both large and small coins, valued in terms of local units of account, fell. In the case of small coins, this happened through debasement (reducing the metal content of a particular coin); for large coins, through enhancement, or 'crying up' the money (that is, increasing the nominal value, in units of account, of a particular coin). ${ }^{15}$ 
In his work on the 'dual currency system' of Renaissance Europe, Fantacci (2008) has referred to debasement and enhancement as 'two levers of monetary policy' that allowed the supply of money to adapt to growing demand in an era of recurrent shortages of precious metal. The penny coin was the basis of the 'current money of account' in local markets within Italy. Between 1500 and 1650, the penny had a stable extrinsic value, but its metal content consistently declined. This 'structural' debasement, as distinguished from revenue-raising debasement, was 'a way to offset deflationary pressures and preserve the nominal value of small change, keeping it in circulation' (ibid., p. 65). On the other hand, large coin, used in international trade, had a stable metal content, while its tariff value, in terms of the current money of account, increased more than ten-fold over the same period of time (Cipolla, 1963, p. 418; Fantacci, 2008, p. 61). ${ }^{16}$

Other post-Keynesian research work on metallic money systems has downplayed the significance of the physical manifestation of money as coined metal. In his work on the historical origins of money, Wray (1993) stressed the historical and functional primacy of the unit-of-account function of money. Long before the appearance of coined money, parties to market transactions wrote debt contracts in terms of some unit of account - 'money'. Even after metal was coined into money, contracts were written in terms of 'imaginary money', or 'ghost money', meaning monetary units of account that had no physical counterpart in the form of 'real' means-of-payment money (ibid., pp. 13-15). ${ }^{17}$ Wray (ibid., p. 26) asserts that the 'quantity of commodity money available ... never constrain[ed] the money of account supply'. But even if debt contracts were written in terms of a 'money of account' that no longer circulated, they still had to be actually settled in some real money form, namely coinage (presented at a value in terms of the current money of account).

In her work, Bell (1998) has advanced the chartalist view that metallic money's value was rooted in its extrinsic or tariff value set by the State, not in its intrinsic value. Certainly the extrinsic value was predominant in cases where the metallic content of a coin was worn away through use, but it was still accepted at its full face value. Yet, according to Fantacci's (2008) 'dual currency' interpretation, the intrinsic value of coin was important in the international circulation of goods and money. Merchants involved in international trade received payments in a variety of local monies of account that had to be converted to some uniform measure, a consideration missing from Bell's (1998) single-state perspective. This uniform measure was provided by the metal content of the coin in terms of weight and fineness. ${ }^{18}$

In sum, there were elements of both endogeneity and exogeneity in the supply of minted coin in Medieval and Renaissance monetary systems. 
Unlike the gold standard of the nineteenth century, the relationship between a physical quantity of metal and the unit of account was not fixed, but variable. This provided an important degree of freedom from the physical conditions of mining precious metals in the pre-industrial age. However, if the authorities got mint prices wrong, which was all too easy to do, the economy was subjected to 'supply shocks' in the stock-and-flow supply (through minting) of coined money, as coinage was exported or melted.

\section{'Inside Money' Forms}

Adherants of the strong or 'revolutionary' position on institutions and money endogeneity could, perhaps, grant that metallic money was not supplied in a smooth, endogenous fashion, like the notes and deposits issued by modern-day central banks, but argue that there were effective credit money substitutes that made up for the deficiencies of metallic money. There were, indeed, banks and networks of trade credit in early modern European economies, but they were only partial solutions to the shortage of metallic money. ${ }^{19}$

Let us briefly discuss three types of non-coin means of payment: bills of exchange, assignable letters of credit, and deposits issued by clearing banks. Bills of exchange, first used at the end of the thirteenth century, offered an early solution to the high cost of making large payments with bullion, especially over long distances. ${ }^{20}$ Merchant-traders drew bills of exchange on each other to finance trade; these bills were remitted and cleared using the services of an international network of exchange bankers located in the major trading cities of the European economy. BoyerXambeu et al. (1994, pp. 129-30) link the rise of bills of exchange to the deficiencies of metallic money: by 'making it possible to transfer funds without transporting coins, exchange by bills enabled intra-European merchandise trade to develop without the constraints of liquidities at a time when local merchants constantly complained about the shortage of metallic coins of good quality and their manipulation by the princes'. ${ }^{21}$

In northern Europe, merchants made payments using a similar instrument, called 'writings obligatory', which were simply promises to pay in the future. Great advances were made in the rising commercial cities of sixteenth-century Antwerp and Amsterdam in improving the transferability, or negotiability, of commercial credit instruments. For debt instruments to circulate as a means of payment, they had to be legally assignable to a third party (other than the original parties at the time the debt was created). Bills of exchange and writings obligatory had bearer clauses, and early in the sixteenth century an Antwerp court 
gave the 'bearer' the same legal protections as the original creditor. The practice of endorsement by successive receivers emerged after 1600, which further strengthened 'the practice of paying debts with paper instruments, without the use of currency' (Van der Wee, 1997, p. 183). Circulating credit instruments with bearer clauses were an important transitional form between metallic money and bank notes. ${ }^{22}$

Clearing and deposit banks were essentially bookkeeping systems used to make book transfers between merchants, in settlement of net debts rising out of trade. The Venetian bankers of the sixteenth century were known as banchi di scritta, banks 'which did business by writing transfers of deposits from one account to the other' (Lane, 1937, p. 190). Payments were made by 'the two parties appearing before the banker and personally ordering the transfer made on his books' (Lane, 1937, p. 190). For Spufford (1988, p. 259), such banks did not alleviate deficiencies with metallic money, since they developed 'not where the money supply was poor, but in places where the money supply was already most abundant', such as the cities of northern Italy, and, later, the southern Netherlands (see also Lane, 1937, pp. 190-205). ${ }^{23}$

In the seventeenth century, London goldsmith-bankers issued certificates that circulated at large, not just within the circle of depositor-traders who held accounts with a goldsmith-banker. The smooth circulation was backed up by interbank lending in the clearing process, a practice that, as shown by Stephen Quinn's work, set the goldsmith-bankers apart from the earlier deposit banks:

Entries in the ledgers of Amsterdam's Wisselbank (Exchange Bank) always listed a corresponding counter party other than the bank. This was because the Wisselbank only honoured orders to pay backed by positive balances. ... London's goldsmith-bankers cleared debts without regular cross referencing (referral to an offsetting counter party account). Instead of clearing between accounts, Backwell [one goldsmith-banking firm] himself became a principal. $[\mathrm{He}]$ assumed the offsetting debits and then later cleared the transaction. By stepping into the clearing process as a counter party, Backwell created credit. (Quinn, 1995, p. 75)

Backwell's lending ensured the timely payment of debts between the other banks in the clearing network, which allowed goldsmith certificates to circulate among the non-bank public without interruption. In this way, the goldsmith-bankers' interbank clearing mechanism was an important institutional innovation in the evolution towards endogenous money.

The use of paper or 'book' credit instruments such as bills of exchange, writings obligatory and bank deposits added flexibility to the late Medieval monetary system, but its scope was limited to large-scale commercial 
transactions. Spufford (1988, p. 395) emphasizes that 'the great body of commercial transactions, and in consequence of monetary payments, was intensely local in character. ... Inside the town, as in the country, most transactions were met by payments in coin' ${ }^{24}$ Furthermore, although these instruments reduced the need for coined money as a means of payment, payees could insist on receiving payment in coin, and final settlement between issuers of inside money required coin.

To summarize, the 'needs of trade' were often compromised in the early modern monetary system, whether by discontinuity in the supply of precious metals (lags in the opening of new sources) or the inherent challenges of managing metallic money. The issuance of large coin-substitutes (bills of exchange, clearing bank liabilities, assignable letters of credit) as early forms of 'inside money' added elasticity, but was geographically and functionally limited to the more commercially dense locations of the European economy. Shortages of metallic money remained particularly binding in the smaller-denomination transactions of urban wage-earners and tax-payers.

Metallic money was not the only money form in the era before central banks: there were also paper-money systems. We might expect these systems to be far more 'endogenous' than metallic-money systems, given their degree of freedom from physical stocks of precious metals. The following section examines how well the paper-money systems that evolved in the United Kingdom from the metallic-money systems of western Europe worked from an endogenous-money perspective. The results were mixed: in some ways, metallic-money systems were more flexible than the paper-money systems that followed them.

\section{PAPER-MONEY SYSTEMS OF GREAT BRITAIN AND THE NORTH AMERICAN COLONIES}

This section analyses the supply-side characteristics of paper-money systems in the United Kingdom and British North America between the chartering of the Bank of England in 1694 and the Anglo-American banking crisis of 1825-26. Three specific types of paper-money-issuing institutions in the pre-central-banking period are examined: public banks chartered by national governments, unincorporated banks, and colonial governments in British North America.

The 'paper money' era corresponds to Stage 1 in Chick's (1986) model of banking system evolution, during which bank money has not yet replaced specie as a means of payment, and there is no central bank. In the late seventeenth and early eighteenth centuries, paper money was an unfamiliar 
and untested form of money, one which exposed holders to some degree of credit risk. The main project, from a monetary development point of view, was to build public confidence in paper money.

The institutional device that was adopted to build confidence in bank money was to make it convertible on demand into the standard asset (silver or gold) at a fixed rate of exchange. ${ }^{25}$ With the adoption of paper money on a gold or silver standard, the unit of account and the medium of exchange became merged in national monies. As trading partners all joined the gold or silver standard, they collectively created a fixed exchange-rate regime internationally. The shift to a specie standard turned out to be a mixed blessing for the monetary authority. On the up-side, the fixed exchange-rate regime meant that private arbitrage operated only within relatively narrow specie points, so national economies were less exposed to destabilizing specie 'shocks' from private arbitrage. However, authorities could no longer increase the money supply by declaring that a certain piece of printed paper was now worth more units of account. Domestic money growth was now potentially more constrained by the stock of precious metals than it had been in the metallic-money era, particularly if there was as yet no central bank.

Historically, large public banks, chartered by national governments for fiscal purposes, played important roles during the gap in time between metallic money and modern money. Most important for the issue at hand, the public banks relaxed the specie constraint by issuing notes and deposits that functioned as 'near-standard assets'. This additional layer in the monetary hierarchy allowed greater leveraging of the stock of inside money on the specie stock in classic pyramiding fashion. Their large size and close relationship to the central treasury tended to pull them into larger systemic roles, needed in the more crisis-prone world of credit money. They typically held large shares of the stock of specie in the banking system, so their holdings inevitably became a 'central reserve', the protection of which required that they engage in certain kinds of stabilization operations.

However, the public banks were not fully fledged central banks. Ultimately, in a deep crisis these stabilization operations would eventually become constrained by the public banks' own mandate to maintain convertibility of their liabilities into specie. In addition, the public banks' charters erected barriers to the entry of similarly scaled rivals while also limiting the growth of the public banks themselves. Both kinds of charter restrictions limited the capacity of the banking system compared to the modern system of corporate banks backed by central banks. These contradictions were only resolved with the public banks' evolution into central banks. 


\section{The Public Banks}

A limited number of large, note-issuing public banks were chartered in the financial centres of the United Kingdom and North America between the late seventeenth and mid-nineteenth centuries, including the Bank of England (London, 1694), the Bank of Scotland (Edinburgh, 1695), the Bank of Ireland (Dublin, 1783), the First Bank of the United States (1791), and the Second Bank of the United States (1816). ${ }^{26}$ These banks were created to bolster the finances of the central treasury; in return, the governments bolstered the financial strength of the public banks.

The Bank of England was chartered in the middle of a dual crisis: a public finance crisis associated with the conduct of the Nine Years War, and a monetary crisis associated with the Great Recoinage of silver money. The Bank was organized as an investment trust with a defined lifetime for the purpose of lending 1.2 million pounds to finance the government's war with France. ${ }^{27}$ The loan to the British government was structured as a perpetual annuity, with interest payments to the Bank coming from a 'perpetual' fund created from a new tax on ship tonnage and on liquors. In exchange, the Bank was permitted itself to borrow an equal amount in the form of bills 'assignable by endorsement'. ${ }^{28}$ The Bank's corporate privileges were to cease when the government's debt was retired, after a period of at least 12 years. Instead, over the course of the eighteenth century, the Bank's charter was renegotiated and renewed a number of times, always in connection with the demands of war finance, and always resulting in the strengthening of both the Bank and the government as borrowers.

In 1697, a fiscal and monetary crisis stimulated the first renegotiation of the Bank's charter. A large part of the accumulating government debt in the form of 'tallies' were taken off the market and 'ingrafted' into a new issue of Bank stock; in exchange, the government pledged that no other corporate bank would henceforth be chartered by an Act of Parliament, and expanded the Bank's authority to issue notes (Andreades, 1924, pp. 110-11; Clapham, 1944, pp. 60-67; Dickson, 1967, pp. 373-9, 387-92; Bowen, 1995). Ten years later, in 1707, when the government, engaged in a new war, looked to issue much larger volumes of short-term debt, it again turned to the Bank of England. The charter renegotiation of 1707 allowed the Bank to continue to operate so long as the debt was unredeemed by the government; solidified the Bank's role in mediating payments between the public and the central treasury; and bolstered the Bank's monopoly with the adoption of legislation stipulating that 'no [other] corporation or partnership of more than six persons should borrow, owe, or take up any Sum or Sums of Money on their bills or Notes payable at demand or at any less Time than Six months' (Clapham, 1944, p. 65). 
The monetary crisis that gave rise to the Bank of England's monopoly privileges also gave birth to the Bank of Scotland. The available stock of gold coins in Scotland was depleted for export to England, creating an insufficiency of currency. After the organization of the Bank of Scotland in 1695, notes replaced coin in the circulation of tax receipts and government payments to military suppliers (Saville, 1996, p. 17). After the formation of the United Kingdom in 1707, Scottish residents and businesses paid taxes to the British government, so that the Bank's fiscal role shifted to one of ensuring convertibility between the Scottish pound, in which Scottish incomes were earned, and the English pound, in which tax liabilities were owed. Unlike the Bank of England, the Bank of Scotland was given a monopoly of corporate banking in its original charter, which the Bank allowed to 'lapse without protest' in 1716, opening the way for the chartering of the Royal Bank of Scotland in 1726.

The Bank of Ireland was chartered in 1782, during a brief period of Irish legislative independence, as part of a programme to place Irish public finance on a sound footing. Subscriptions to the Bank's stock were payable in government debt valued at par, which exceeded its market price. Public monies were to be deposited in the Bank instead of being held by receivers, paymasters and varieties of treasurers. In exchange for the Bank's fiscal and administrative services, it was also given a monopoly of chartered banking. The Bank's central role in public finance continued after the Union of the Irish and British parliaments in 1801, until the Exchequers of Great Britain and Ireland were merged into one Treasury Board in 1816. The Bank's monopoly privileges were eroded after the country banking crisis of 1820 (Hall, 1949).

The First and Second Banks of the United States were both chartered following wars (the Revolutionary War and the War of 1812), to reorganize and stabilize central government finance. Shares of both banks could be purchased with government debt valued above its market price, effectively removing an overhang of public debt from the market. Both banks were closely tied to the fiscal adminstration of the central government, and in both cases the federal government agreed to charter no other banks. ${ }^{29}$ Their notes, which were required by charter to be convertible into specie or its equivalent, provided a medium for collecting taxes that would convert without loss into the foreign currencies of creditor countries. Both banks issued the highest-quality notes in the banking system; by 1830 the Second Bank supplied 20 per cent of the money supply. During the life of the Second Bank, the banking system's share of the national specie stock rose, and banks' reserve ratios fell, both of which are evidence of growing confidence in banks. ${ }^{30}$ Both banks were subject to a ceiling on their capitalization, and neither had its 20 -year charter renewed. 
From a credit quality point of view, the liabilities of the public banks were somewhere in-between the notes of other banks and specie, giving them the status of 'near-standard assets'. Since central government debt was payable with the notes and deposits issued by the public banks, it was particularly important that their convertibility into gold or silver be maintained. The public banks tended to have higher reserve ratios and higher shares of public debt than their private counterparts, which reduced the liquidity risk and default risk of their notes. ${ }^{31}$

The other banks in the system had at least two reasons to hold public bank liabilities even though they were not required to do so. First, central governments invariably made the notes and deposits of 'their' public banks legal tender in payments to the government. Because taxes were payable in the notes of the public banks, but collected in the notes of all banks, other banks had to hold notes of the public bank in order to clear payments due to the public bank. Second, public bank notes were an attractive secondary reserve asset. As public bank lending expanded over time, so did the stock of 'near-standard assets' in the form of public bank notes and deposits. Public bank liabilities did not yet replace specie as bank reserves, but they did serve as a supplementary reserve.

The public banks were, to some extent, stabilizing forces in their national banking systems, but their behaviour was ultimately constrained by the rules of the specie standard. The Bank of England contracted lending during crises until the latter decades of the eighteenth century, by which time its own notes were 'beyond reproach'. After 1763, the Bank increased its discounts of bills of exchange when bankruptcies were on the rise, as a counter-cyclical response to credit-market stress. Still, once its specie reserve reached a low point, the Bank rationed credit to protect its liquidity (Lovell, 1957-58, p. 12) ${ }^{32}$ In the early nineteenth century in the United States, there are instances when the First and Second Banks extended forebearance to individual cash-strapped State-chartered banks, but they could not be counted on to increase their liabilities during liquidity crises. At such times the public banks would do what every other bank was doing: contract credit and withdraw liabilities in order to maintain their convertibility into gold or silver (see Timberlake, 1961, p. 335). ${ }^{33}$

The public banks played an important but contradictory role in the process of monetary development. With their own commitment to specie convertibility, and their position as fiscal agent at the centre of the banking system, the public banks helped build public confidence in bank notes. Yet they stopped short of providing liquidity on demand to the banking system during panics. Their political, therefore economic, survival was not assured. Unlike modern central banks, their charters were granted for a defined period of time. Charters were usually (not always) renewed, and 
capital authorizations were expanded, but these were contingent on the vagaries of political life. Finally, the public banks were not chartered at a scale that would have allowed them to meet the entire economy's demand for money, and their charters limited the entry of larger, joint-stock competitors. ${ }^{34}$ In the rest of the British Empire, paper money was supplied, imperfectly, by unincorporated banks and colonial governments.

\section{Unincorporated Banks}

Unincorporated banks did not operate under government charters, so they could enter spontaneously and 'endogenously', based on changing conditions of cost and demand, and owners' willingness to commit capital to the business. However, their unincorporated status imposed limits on their scale and financial resilience. Banking firms that barely achieve minimum viable scale are financially fragile, and operate on small margins. ${ }^{35}$ It takes only a small shock to cost or demand for the bank's viability to be tested, either by operating deficits or reserve deficiencies. Banking systems populated by small unincorporated banks experience high rates of entry and exit, with unclear effects on the holders of their liabilities. When the owners of unincorporated banks declared bankruptcy, the value of their notes presumably fell to some degree, wiping out some share of the money stock in a manner completely disconnected from changes in the demand for money.

The first banking crisis of the paper-money era took place after the 'Stop' of the Exchequer in 1672, when the English Exchequer stopped payments on part of the government's short-term debt in order to free otherwise-committed funds for new wartime expenses. Those goldsmith-bankers with the greatest concentration of their assets in loans to the central government defaulted on their notes. The notes issued by the goldsmiths ceased to be accepted as means of payment, and were even rejected by the British government itself, claiming that their notes were 'not now money' (Horsefield, 1982, p. 523). ${ }^{36}$ The unincorporated status of the London goldsmith-bankers intrinsically limited their scale and ability to absorb large losses. After the establishment of the Bank of England, the London private bankers stopped issuing their own circulating bank notes, and used Bank of England notes instead (Clapham, 1944, p. 166).

The number of unincorporated country banks in England and Wales increased sharply after 1750, from not more than a dozen to 600 by 1820 (Pressnell, 1956, p. 11; Anderson, 1970, p. 100; Newton, 2007, p. 2). Even so, the country note issue failed to fully substitute for coin in the circulation of wages and wage goods, in part because the government made small notes effectively illegal after 1775 (Feaveryear, 1963, pp. 174-5). ${ }^{37}$ According to 
Ashton (1955, p. 173), 'the deficiency in the quantity of silver money was a handicap to the development of retail trade and to the rise of a wageearning class.... Much time was spent [by employers] riding about the country in search of cash with which to pay wages, and in the northern and western parts of England the dearth of coin was often acute'. ${ }^{38}$ The persistent demand for silver from overseas, particularly the Far East (where the market value of silver was 10 per cent higher in terms of gold than in England), kept the London market price of silver above its mint price, a continuation of seventeenth-century monetary problems.

Financial crises brought high failure rates and contractions of the note issue. After the crisis of 1793 , the country note issue fell to less than half what it had been a year earlier; another wave of country bank failures took place between 1810 and 1816. In the financial crisis of 1825-26, 80 country banks and two major London banks failed. The small scale of the country banks rendered them vulnerable to changes in their operating environment, which in the early 1820 s included postwar deflation, agricultural depression and the resumption of specie payments (Feaveryear, 1963, p. 186). ${ }^{39}$ In response to the banking crisis, in legislation adopted in 1826 the UK Parliament eroded the Bank of England's monopoly by allowing the formation of larger (more than six members) banking co-partnerships (joint-stock banks with unlimited liability) outside of a 65 -mile radius of London. An 1833 Act explicitly permitted non-note-issuing joint-stock banks in London. The UK Parliament also called for the establishment of Bank of England branches in provincial cities. The intent, and effect, of these laws was to foster the development of a banking industry populated by fewer, larger banking firms in both London and the provinces, and to draw the Bank of England into taking on more responsibility for the stability of the banking system. ${ }^{40}$

In Ireland, the story was very similar. Private banks first appeared in Dublin in the early 1700s, and carried on an active exchange banking business with correspondents in London and provincial trading centers. After 1750, private banking in Ireland spread to the provinces. Following the failure of three Dublin banks, a 1756 Act of Parliament prohibited merchants engaged in foreign trade from being bankers, and required the names of all partners in a bank to appear on its notes. Joint-stock banking was suppressed by the 1756 law, and then by the 1783 chartering of the Bank of Ireland. After the financial crisis of 1820, during which several Dublin-based private banks and a number of country banks failed, the six-partner rule and the restrictions in the 1756 legislation were removed. Joint-stock banks with more than six partners could now be established outside of a 65-mile radius of Dublin (Munn, 1988, p. 73).

In Scotland, joint-stock banking developed earlier than in England and 
Wales, with beneficial banking-system effects. Neither the six-partner rule nor the Bubble Act, prohibiting the formation of joint-stock companies without a charter from the Crown, applied to Scotland. ${ }^{41}$ Joint-stock banks had many more partners, larger capital, more branches, and larger assets, on average (assets of 2.1 million pounds as compared with 0.24 million pounds in 1825). As in England and Ireland, the number of provincial banks increased significantly after 1750 . The small provincial banks survived so long as they operated as local monopolies in local banking markets. They failed, exited voluntarily, or were merged into a larger banking organization when they became too small to compete in an industry increasingly characterized by excess capacity and economies of scale. ${ }^{42}$ By 1845 , all but four of the 87 unlimited-liability partnership banks opened since 1695 had either closed, failed, or been taken over or merged into another banking organization, usually one of the public or joint-stock banks. ${ }^{43}$

The Scottish banking industry experienced a lower failure rate than the English in the crisis of 1825-26, reflecting the effects of larger bank sizes, better techniques for the diversification of risk, and the 'supervisory' functions provided by the publicly chartered banks. ${ }^{44}$ Bowen and Cottrell (1997) have pointed out, though, that the Scottish banking system was hardly perfect: 20 per cent of all provincial banking companies formed in Scotland 'closed their doors' during the period up to 1830, 'almost approaching the level of bank failure in England and Wales - one in three' (ibid., p. 102). ${ }^{45}$

\section{Fiat Money}

Prior to independence, the American colonies' efforts to charter banks were also stymied by the six-partner rule. In 1730s and 1740s New England, two associations received charters from their colonial governments to issue circulating bills, which were subsequently rescinded or suppressed by Parliament (Brock, 1975, pp. 50-54). ${ }^{46}$ Instead, the colonies issued colonial currency, which was legal tender in both public and private transactions until prohibited by Acts of Parliament in 1751 and 1764 (ibid., pp. 238-9, 526). ${ }^{47}$ One might expect colonial currencies to perform well from an endogenous money perspective: they were credit-based, they were not legally payable into specie, and their issuers were not likely to declare bankruptcy. But the conditions governing their supply were political, and therefore disconnected from the demand for money.

Colonial bills of credit were issued either as tax anticipation notes to finance colonial government budget deficits, or as mortgage notes to finance private acquisition and improvement of land. Both types of bills 
had backing mechanisms that provided for the retirement of the notes. Tax anticipation bills, or tax notes, were issued with fixed expiration dates at which the bills were to be retired from identified tax sources. Tax notes could stay in circulation beyond their redemption dates if the government failed to raise the revenues necessary to redeem them, but their acceptability as money depended on their being retired 'on schedule'. ${ }^{48}$ Mortgage notes were to be retired as borrowers repaid their loans, and could be reissued with the extension of new mortgages.

For the stock of tax notes to grow, there had to be growing and persistent public sector deficits. Colonial governments routinely ran deficits and emitted new issues of tax notes during wartime, and then withdrew them at the end of the war. Clearly, this pattern of issuance and withdrawal created a disconnect between currency finance and the demand for money, one that was clearly demonstrated in the very first emission of bills of credit. Massachusetts issued tax notes, in 1690, to finance the wages of soldiers returning from an expedition to Quebec during Queen Anne's War. The conclusion of the war brought the retirement of the bills, causing merchants to complain that the number of bills in circulation bore 'little Proportion to the business of the Country' (Brock, 1975, p. 26).

Another example of the limited endogeneity of currency finance comes from the colony of New Jersey. New Jersey issued mortgage-backed currency in the 1720s and 1730s, and bills of credit in the 1740s to finance the colony's contribution to Britain's waging of the third French and Indian war. But the per-capita stock of bills of credit declined continuously in the 1740s, and the colonial legislature's efforts to emit more loan office bills, in response to the demands of constituents, were vetoed by the British authorities. This historical record resonates with Eichner's (1991) fundamental critique of fiat money, that public bodies issuing it would be 'subject to political pressures that reflected a different dynamic from that governing the economy' (ibid., p. 810).

In the system of colonial currency finance, the demand for money was conveyed, and could be blocked, through a political process. Given the political and public-finance factors governing the emission and withdrawal of colonial bills of credit, we would not expect to see a close relationship between the stock of bills and short-run demand in the real economy. This was confirmed in a quantitative study by Rousseau (2006), who found that the supply of colonial bills of credit was largely disconnected from demand in the short run, but grew in proportion to population growth over the long run. ${ }^{49}$

The application of the currency finance model to the colonies' war with Britain ended in rapid depreciation of the Continentals, and the decision to turn war finance back over to the State governments. After the 
war, Alexander Hamilton issued a report on banks, which proposed the establishment of the Bank of the United States as part of his larger project of establishing US finance on a solid footing. Hamilton (McKee, 1934, pp. 72-3) said of fiat currency issued by government that 'there is no standard to which an appeal can be made, as to the quantity which will only satisfy, or which will surcharge the circulation'. But in the case of paper currency issued by a bank, 'that standard results from the demand. If more should be issued, than is necessary, it will return upon the bank' (ibid.). ${ }^{50}$

\section{CONCLUSION}

In this chapter I have agreed with Chick's (1986) position that money did not become fully endogenous, in the sense of its quantity being demanddetermined, until the development of central banks. But the monetary history of metallic- and paper-money systems in the period before central banking provides considerable support for the Rochon and Rossi (2013) position that money is 'intrinsically' endogenous as well. The historical record shows that once society has a need for money, there will be some kind of social mechanism to increase the supply as the need for money grows. This social mechanism, however, was not perfected until the emergence of central banks.

Metallic-money systems had, in one sense, the ultimate endogeneity mechanism: the monetary authorities could increase the money supply by simply declaring that a certain coin was now worth more, measured in terms of the local unit of account. The secular rise in mint prices increased the ratio of domestic money supplies to stocks of precious metals. It was nearly impossible, though, to prevent short-run shifts in the supply of coined money as arbitrageurs profited from gaps between mint prices and market prices in different locales. Metallic money gave way to paper money in the eighteenth century. As trading partners all moved onto the specie standard, domestic money supplies were less exposed to destabilizing, arbitrage-driven specie movements, but more exposed to credit crises and rapid shifts in the public's willingness to hold paper money. The ratio between ounces of gold or silver and number of units of account was now fixed, which potentially tied the growth in means of payment more closely to growth in stocks of gold or silver than it had been three centuries earlier.

Public banks played an important but contradictory role in monetary development during the 100-year transition between the adoption of the gold (or silver) standard and the emergence of central banks. The notes and deposits issued by the public banks came to be regarded as close substitutes for high-powered money as a circulating medium, and then as a secondary 
reserve for the banking system. Other banks were much smaller than the public banks, weakened in some places by the privileges and protections extended to the public banks by their chartering authorities. The public banks were not created for central-banking purposes, but their size and relationship with the central treasury drew them into a stabilization role, one which was ultimately limited by the public banks' own specie holdings and minimum liquidity requirements. These institutional contradictions persisted until the public banks evolved into central banks.

\section{NOTES}

1. In this chapter I consider money to be endogenous when its quantity is demanddetermined. When money is endogenous, changes in nominal income determine changes in the stock of money, instead of the other way around. See Desai $(1989$, p. 146) and Smithin (2003, p. 98).

2. Note that the exogenous factors that determine the quantity of deposits may or may not constrain the level of nominal income in Stage 1.

3. For Lavoie (2006, p. 21), who places himself in the 'accommodationist' strand, 'the full endogeneity of the supply of high-powered money does not in general arise from the 'lender of last resort' role of the central bank or from its willingness to engage into open market operations; rather it arises from the procedures through which the central bank can operate the clearinghouse'. Specifically, the central bank must 'provide on demand the required level of high-powered money' (ibid.). See Fullwiler (2003) for a detailed institutional description of this behaviour by the Federal Reserve in the United States.

4. If agents could always issue their own money, there could never be a scarcity of money. The fact that the money-issuing capacity is always reserved, through some kind of political or social process, for certain entities and not for others speaks of money's essential character as a socially established standard of value.

5. Thus, Rochon and Rossi (2013, p. 224) insist, there can never be an excess supply of money. This idea lies at the heart of the post-Keynesian critique of the monetarist metaphor of money supply as a helicopter drop.

6. The 'standard asset' also, necessarily, serves as the unit of account. The distinction between the standard asset and all circulating media is essentially the same as Gurley and Shaw's (1960) inside-money/outside-money construction. Wray (1993) and Bell (1998) also discuss the hierarchy of money forms.

7. In Innes's (2004) 'Credit theory of money', coin is considered credit money in that it represented the State's promise to accept the coin in the future in payment of taxes.

8. This terminology follows Redish (2000, p. 27).

9. The ratio of the intrinsic value (units of account in a given coin) to extrinsic value (ounces of metal in a given coin) yields the mint price (units of account per ounce of metal).

10. Mayhew $(1999$, p. 7) goes further and states that 'taking the long view ... the major spurts of supply have occurred independently from shifts in demand'.

11. The relationship between supply- and demand-side factors was complex. Nef (1952, p.458) argues that 'a renewal of prosperity in mining depended upon general improvement in economic and political conditions', but then attributed sluggish demand conditions to 'the unsatisfactory yield of the mines and the mints from which ... princes often derived a portion of their revenues', given that 'orders for industrial products came from the great princes and still more from the Church'. Spufford (1988, ch. 15) 
advances more of an exogenous-supply-side interpretation. Sargent and Velde (2002, pp. 10, 124-5) dispute the idea of a bullion famine altogether. In their view, the real problem was a shortage of minted coin, not a shortage of mintable metal.

12. Sargent and Velde (2002, p. 10) ask '[h] ow can shortages [of coin] occur when people can always use silver to purchase new coins from the mint? The answer is that people want to convert metal into coins only if it is profitable to do so'.

13. According to a petition to the king of England in 1446 (Sargent and Velde, 2002, p. 134), 'the poor common retailers of victuals, and of other needful things, for default of such coin of half pennies and farthings, oftentimes may not sell their said victuals and things, and many of our . . . poor liege people ... may not buy them, for default of half pennies and farthings, . . . because that for their great weight, and their fineness of ally, they be daily tried and molten, and put into other use, unto the increase of winning of them that do so'. In Sargent and Velde's (2002) model, shortages of small coin set into place a dynamic in which small coin eventually reaches the 'melting point' at which its value as metal exceeds its value as a means of exchange - a perverse supply response to an inadequacy of small coin.

14. Van der Wee (1977, p. 297) observes that gold-silver ratios in different countries were 'never uniform or in equilibrium with each other'. Supple (1957) described the European economy as being 'perennially at the mercy of volatile movements of bullion owing to the operations of a badly tariffed and frequently manipulated bimetallic system' (ibid., p. 252), adding '[y]et great technical difficulties existed in the estimation of foreign and market ratios, in the fixing of a true rating [or tariff], and in securing approval for any particular policy. It was therefore only to be expected that errors would be made, or go uncorrected, and that neighbouring countries would establish ratios differing sufficiently from each other to afford the possibility of a profitable trade in bullion and specie' (ibid., p. 251). Kindleberger (1991, p. 151) agrees that 'getting the currency right in this period posed difficulties because of rapidly changing relative supplies of gold, silver and copper and the opportunities this gave to exercise Gresham's Law'. Unregulated minting and currency debasement in southern German states led to a 'breakdown in trade between town and country' (ibid., p. 165) and to riots among urban workers, as the resulting inflation reduced the real incomes of farmers and wage-earners.

15. The 'mint equivalents' of gold and silver in England and France rose steadily, in stepwise fashion (barring periods of debasement for revenue-raising purposes, during which mint equivalents could change dramatically in short periods of time) between the fourteenth and eighteenth centuries (Redish, 2000, p. 44). Redish's (ibid.) measure reflects the joint effects of debasement and enhancement. The 'clipping' of coins to melt and sell to brokers of precious metals was a private-sector mechanism that produced the same result as debasement by monetary officials.

16. With regard to the public's continued willingness to use debased small coins, Van der Wee (1977, p. 295) notes that 'the habit of maintaining the basic coins as the foundation for the current money of account, even if they were new and contained a smaller weight of silver, was so strong among the majority of the population that it could be safely speculated on' by the authorities. But 'the rates of the large silver and gold coins in current money of account inevitably went up' (ibid.).

17. The idea of 'imaginary money' has come into question in more recent research in Medieval monetary history than that cited by Wray (1993). Spufford (1988, pp. 413-14) calls the term 'imaginary money' a misnomer, since 'on closer inspection an historical explanation may be found for the existence of each money of account, and that such an historical explanation will indicate to which real coin the system continued to be attached'. Van der Wee (1977, p. 290) similarly observes that 'usually a real coin with its multiples or divisions would form the basis of the current money of account'.

18. Until the fourteenth century, ingots of silver, that is, unminted metal, were used for large payments throughout Europe and for payments outward from Europe. At some point in the thirteenth century, ingots were stamped with civic emblems of guarantee. 
During the period that the northern cities of Italy functioned as the financial centre of western Europe, and the financial link between East and West, the Italian florin was the international unit of account, and the measure by which large coins, minted anywhere, were valued - based on their metal content. See Spufford (1988, ch. 9).

19. According to Cipolla (1963, p. 418), the use of 'new and more advanced ... modes of payment' was an inadequate solution to the inelastic supply of precious metals.

20. In my estimates of the cost of shipping specie as a means of payment in the nineteenth century American economy, I found that insurance comprised between one-half and three-quarters of the total cost. Insurance costs were likely to have been even more burdensome in early modern Europe (Knodell, 1998, appendix tables 1 and 2). Spufford $(1988$, p. 254) argues that some level of regularity and scale of trade had to be reached for international merchants to develop the 'mutual confidence' required for the use of the bill of exchange, which, unlike gold or silver coin, was a credit instrument with default risk.

21. Boyer-Xambeu et al. (1994, p. 155) point out that 'exchange by bills released minted metal for internal circulation'. The authors argue that 'exchange by bills' was profitable until the founding of nation-States in the seventeenth century, when seigniorage was replaced by taxation and units of account were merged with means of payment in national economies. Exchange by bills was systematically profitable for exchange bankers because of the asymmetric nature of seigniorage, meaning the fact that seigniorage did not apply to coins minted by foreign authorities.

22. Bills of exchange in the southern European system described by Boyer-Xambeu et al. (1994, p. 31) tended not to include a bearer clause, since 'those who controlled the network of exchange by bills - namely, the Italian exchange bankers - [rejected] such transmissibility constantly and resolutely'.

23. In other Italian banking cities, checks circulated among depositors. Spufford (1988, p. 257) refers to this as 'transfer banking'.

24. Even in Venice, according to Lane $(1937$, p. 191), only one of every 30 residents of Venice had a bank account. The use of credit in the hinterlands did not reduce the need for metallic coin: according to a historian, 'the deeper penetration of finance into the local economy caused the need for payments in money to increase more than proportionately to the availability of small metal coinage' (Van der Wee, 1977, p. 300).

25. Redish (1993) considers the precious metals as the 'anchor' for early paper-money systems. For Wray (1993, pp. 25-6), credit money was made convertible into the 'risk-free representation of the social measure of value' to make the default risk on bank liabilities 'palatable'. Silver and gold were 'outside money', not because of their value as precious metals, but because, as the standard asset, they were riskless monetary assets.

26. Here the term 'public bank' has a dual meaning, referring to banks that were (i) publicly held corporations and (ii) closely tied to the chartering government's fiscal affairs.

27. See Dickson (1967, pp. 54-7). The Bank of England had a lending capacity about ten times greater than that of an average London private bank, and, unlike private lenders, the new corporation was prepared to lend all of its capital to the government. During the Nine Years War with France, the British Exchequer's financing gap exceeded that available from the goldsmith-bankers. The private bankers were unwilling to allow their reserves to fall below a fairly high threshold, for fear of a possible faltering of public confidence in public debt that could lead to a run on their notes.

28. According to Feaveryear (1963, pp. 126-7), the Bank's notes (which carried the seal of the Bank, therefore known as 'sealed Bank bills') were paid out for supplies for the army, and soon displaced inland bills of exchange for long-distance remittances: 'The king's "pay" was bad; but where his tallies would no longer go he could place with ease the Bank's "bills".'

29. On the symbiotic relationship between the First Bank and the central treasury, Sylla (1998, p. 86) explains that, '[b]y design, the federal debt supported the bank, and the bank the debt'. Under the US Constitution, State governments lost the right to issue their own debt instruments as money, but retained the ability to charter their own banks. 
The State-chartered banks could only operate within State borders, while the US banks could establish national branch networks.

30. Rutner (1974, pp. 23-30) provides evidence that Second Bank liabilities were closer substitutes for specie than State bank liabilities were. See also Engerman (1970, p. 727).

31. Smith (1953, p. 47) shows that the Second Bank of the United States consistently had higher reserve ratios than State banks in New York and Massachusetts between 1820 and its demise in 1836. In the eighteenth century, the Bank of England often held bullion reserve ratios over 50 percent; see Lovell (1957-58, pp. 10-11, table II). In each instance cited here, the chartering of a public bank was successful in improving the credit worth of its governmental partner, creating a positive, not negative, symbiosis.

32. It is hard to know whether the Bank of England saw itself as taking responsibility for the stability of the banking system, or was simply trying to contain the crisis to protect its specie reserve. White (1991, pp. 54-5) concludes that the Bank of England was not a lender of last resort in the Bagehot sense of giving assurance before a crisis that credit would be available at some price.

33. Officer (2002) treats the First and Second Banks as central banks on the grounds that their notes and deposits were held as reserves by State-chartered banks. This interpretation of the primary source evidence in the case of the Second Bank is challenged by Knodell (2017). In any event, to the degree that some banks did hold Second Bank liabilities as specie-equivalent reserves, it does not follow that the Bank increased its lending, and liability issuance, during liquidity crises; there is very little evidence that it did. On the First Bank's concern about its specie reserve position prior to the Panic of 1792, see Cowen (2000, pp. 99-100). Both Timberlake (1961) and Cowen (2000) provide examples of financial and banking stabilization by the Treasury, which was not constrained by specie convertibility. Chartering authorities did allow banks to suspend specie payments during periods of extreme financial distress, which relaxed the fixed-monetary-base constraint on money creation.

34. The 'growth of provincial banks was not so much stimulated simply by the need to meet local commercial and industrial requirements, but rather it was also to fill the gap that the Bank of England, or the Mint, could not, or resolutely would not, fill' (Ashton, 1955, quoted by Bowen and Cottrell, 1997, p. 96).

35. A bank becomes viable when it has a reserve ratio that is high enough to meet redemption demands, and low enough to allow profitable intermediation.

36. Horsefield (1982) speculates that the widespread losses among goldsmith-bankers and their creditors postponed the beginning of joint-stock banking in England by undermining the public's faith in the idea of banking.

37. Among the abuses the legislation sought to stem was the practice of redeeming small notes only on condition that the holder of the notes presented enough silver coin with the notes to receive a gold coin in return.

38. Eighteenth-century English employers also adapted to the shortage of small silver coin and currency by giving a group of workers one larger bill, then 'leaving them to divide it among themselves at the public house', or by lengthening the pay period until the wage reached the note-denomination available to the employer (Ashton, 1955, p. 168; see also pp. 172-7, 186-7). Ashton (1955) argues that agency and incentivecompatibility problems were one reason for the undersupply of minted coin. The Mint was 'answerable' to the Treasury, but since the mintmaster's income came from commissions, lucrative private contracts took precedence over orders from the Treasury. Privately minted coin and manufacturers' tokens filled some of the need for a small-denomination circulating currency, with mixed results for the wage-earners who received them in payment.

39. In England and Wales combined, 15 per cent of all banks failed (Collins, 1988, p.9; Bowen and Cottrell, 1997, p.97). The average country banker had less than 10,000 pounds of equity capital and less than the legal maximum of six partners (Pressnell, 1953, p. 393).

40. Partners of joint-stock banks 'remained liable for their debts but the ability to issue 
shares increased the potential number of partners and spread the risk and liability that had been so concentrated with the country bankers' (Newton, 2007, p. 5). Fetter (1965, p. 113) attributes the bank run of 1825 in part to the Bank of England's prior withdrawal of its small notes, 'for timid holders of small notes of country banks, who might have been satisfied with Bank notes of one and two pounds, added to the demand for specie'. At the height of the crisis, the Bank helped stem the run by increasing its discounts, relaxing its collateral requirements, and reissuing its small notes, giving stimulus to the 1826 legislation despite the fact that 'the Bank management does not appear to have been happy at the idea of meeting a rendezvous with central banking destiny' (ibid., p. 119).

41. Scotland became part of the United Kingdom with passage of the Treaty of the Union of Parliament in 1707. The Treaty essentially created a free-trade area, and subjected Scottish residents and businesses to the same laws concerning the regulation of trade, and to the same customs and excise taxes, as English residents and businesses, but made no alteration to laws which concerned private right, which included the right to operate a banking business.

42. With growing interregional trade, the "demand of note holders for a widely acceptable bank note naturally favored the supraregional branch banker over the "local banker" with his narrow circulation' (White, 1984, p. 34; see also p. 7). Dow and Smithin (1992, p.380) argue that there were economies of scale in money production in a system of competing promises to pay resulting from the "nebulous factors of "confidence" and "trust" [which] loom so large in the acceptability of monetary assets from the point of view of those who hold them'.

43. Of the four, three were large co-partneries (Munn, 1981, pp. 86-7, 94; Dow and Smithin, 1992, p. 381).

44. These two banks saw themselves as 'policemen of the system' (Munn, 1991, p. 64). White (1991) considers the Scottish system as a high-performing paper-money banking system that was largely self-regulating. Dow and Smithin (1992) offer a different interpretation of the same historical record. They note that the three public banks were the dominant issuers of the inside-money stock for most of the period between 1700 and 1850, and that as such it was in their self-interest to 'maintain and promote the stability of the banking system in which they had such a large stake' (ibid., p. 381).

45. However, many of the bank closures in Scotland took place through mergers and voluntary closures, which caused less disruption to stocks of money and flows of credit than failures of going concerns.

46. In contrast, in 1822, Canadian provincial governments requested approval from Parliament to charter two banks, whose notes would replace the army bills issued to finance Britain's military defence of Canada during the War of 1812. Parliament did approve these charters, having fresh evidence of the instability of small-scale unlimitedliability banking from Ireland.

47. Under the Act of 1751 , bills of credit would no longer be legal tender in private transactions. The Currency Act of 1764 extended the legal-tender prohibition to public transactions, that is, tax payments to colonial treasuries and loan payments to colonial loan offices.

48. 'Since the money was created and upheld solely by political acts, confidence in the government was essential to its value. The holder had to be confident that withdrawals would be continuous and that future governments would have both the will and the ability to collect taxes. When this confidence existed, the money passed readily in dayto-day transactions without undergoing much scrutiny' (Ferguson, 1961, p.9).

49. The long-run elasticity in the stock of colonial bills of credit must have come from the mortgage note, whose net issuance tracked private ownership and investment in land, which grew in a secular manner over the course of the eighteenth century. Perkins (1994, p. 55) gives colonial currency a generally positive assessment, based on the American colonies' successful economic growth record.

50. On the failure of the Continentals, see Ferguson (1961, ch. 2). 


\section{REFERENCES}

Anderson, B.L. (1970), 'Money and the structure of credit in the eighteenth century', Business History, 12 (2), 85-101.

Andreades, A. (1924), History of the Bank of England, 1694 to 1903, London: P.S. King.

Ashton, T.S. (1955), An Economic History of England: The Eighteenth Century, New York: Barnes \& Noble.

Bell, S. (1998), 'The hierarchy of money', Levy Economics Institute Working Paper, No 231.

Bowen, H.V. (1995), 'The Bank of England during the long eighteenth century', in R. Roberts and D. Kynaston (eds), The Bank of England 1694-1994, Oxford: Clarendon Press, pp. 1-18.

Bowen, H.V. and P.L. Cottrell (1997), 'Banking and the evolution of British economy, 1694-1878', in A. Teichova, G. Kurgan-Van Hentenryk and D. Ziegler (eds), Banking, Trade, and Industry: Europe, America and Asia from the Thirteenth to the Twentieth Century, Cambridge, UK: Cambridge University Press, pp. 89-112.

Boyer-Xambeu, M.-T., G. Deleplace and L. Gillard (1994), Private Money and Public Currencies, Armonk, NY, USA: M.E. Sharpe.

Brock, L. (1975), The Currency of the American Colonies, 1700-1764: A Study in Colonial Finance and Imperial Relations, New York: Arno Press.

Chick, V. (1986), 'The evolution of the banking system and the theory of saving, investment and interest', Economies et Sociétés ('Série Monnaie et Production', 3), 20 (8-9), 111-26.

Cipolla, C.M. (1963), 'Currency depreciation in Medieval Europe', Economic History Review, 15 (3), 413-22.

Clapham, J. (1944), The Bank of England, Volume I, Cambridge, UK: Cambridge University Press.

Collins, M. (1988), Money and Banking in the UK: A History, London: Croom Helm.

Cowen, D.J. (2000), The Origins and Economic Impact of the First Bank of the United States, 1791-1797, New York: Garland Publishing.

Desai, M. (1989), 'Endogenous and exogenous money', in J. Eatwell, M. Milgate and P. Newman (eds), The New Palgrave: Money, New York: W.W. Norton, pp. 146-50.

Dickson, P. (1967), The Financial Revolution in England: A Study in the Development of Public Credit, 1688-1756, New York: St. Martin's Press.

Dow, S. and J. Smithin (1992), 'Free banking in Scotland', Scottish Journal of Political Economy, 39 (4), 374-90.

Eichner, A. (1991), Macrodynamics of Advanced Market Economies, Armonk, NY, USA: M.E. Sharpe.

Engerman, S.L. (1970), 'Note on the economic consequences of the Second Bank of the United States', Journal of Political Economy, 78 (4), 725-8.

Fantacci, L. (2005), 'Complementary currencies: a prospect on money from a retrospect on premodern practices', Financial History Review, 12 (1), 43-62.

Fantacci, L. (2008), 'The dual currency system of renaissance Europe', Financial History Review, 15 (1), 55-72.

Feaveryear, A.E. (1963), The Pound Sterling: A History of English Money, 2nd edn, Oxford: Clarendon Press.

Ferguson, E.J. (1961), The Power of the Purse, Chapel Hill: University of North Carolina Press. 
Fetter, F.W. (1965), Development of British Monetary Orthodoxy, 1797-1875, Cambridge, MA: Harvard University Press.

Fullwiler, S.T. (2003), 'Timeliness and the Fed's daily tactics', Journal of Economic Issues, 37 (1), 851-80.

Graziani, A. (1990), 'The theory of the monetary circuit', Economies et Sociétés ('Série Monnaie et Production', 7), 24 (6), 7-36.

Graziani, A. (2003), The Monetary Theory of Production, Cambridge, UK: Cambridge University Press.

Gurley, J.G. and E.S. Shaw (1960), Money in a Theory of Finance, Washington, DC: Brookings Institution.

Hall, F.G. (1949), The Bank of Ireland, 1783-1946, Dublin: Hodges Figgis.

Horsefield, J.K. (1982), 'The "stop of the exchequer" revisited', Economic History Review, 35 (4), 511-28.

Innes, A.M. (2004), 'The credit theory of money', in L.R. Wray (ed.), Credit and State Theories of Money: The Contributions of A. Mitchell Innes, Cheltenham, UK and Northampton, MA, USA: Edward Elgar, pp. 50-78.

Kindleberger, C.P. (1991), 'The economic crisis of 1619 to 1623', Journal of Economic History, 51 (1), 149-75.

Knodell, J. (1998), 'The demise of central banking and the domestic exchanges: evidence from Antebellum Ohio', Journal of Economic History, 58 (3), 714-30.

Knodell, J. (2017), The Second Bank of the United States: 'Central' Banker in an Era of Nation-Building, London and New York: Routledge.

Lane, F.C. (1937), 'Venetian bankers, 1496-1533: a study in the early stages of deposit banking', Journal of Political Economy, 45 (2), 187-206.

Lavoie, M. (2006), 'Endogenous money: accommodationist', in P. Arestis and M. Sawyer (eds), A Handbook of Alternative Monetary Economics, Cheltenham, UK and Northampton, MA, USA: Edward Elgar, pp. 17-34.

Lovell, M.C. (1957-58), 'The role of the Bank of England as lender of last resort in the crises of the eighteenth century', Explorations in Entrepreneurial History, 10 (1), 8-20.

Mayhew, N. (1999), Sterling: The History of a Currency, New York: John Wiley.

McKee, S. (ed.) (1934), Alexander Hamilton's Papers on Public Credit, Commerce, and Finance, New York: The Liberal Arts Press.

Munn, C.W. (1981), The Scottish Provincial Banking Companies, 1747-1864, Edinburgh: John Donald.

Munn, C.W. (1988), 'The emergence of joint-stock banking in the British Isles: a comparative approach', Business History, 30 (1), 69-83.

Munn, C.W. (1991), 'Comment on Chapter 2', in F. Capie and G.E. Wood (eds), Unregulated Banking: Chaos or Order?, New York: St. Martin's Press, pp. 63-7.

Nef, J.U. (1952), 'Mining and metallurgy in Medieval civilisation', in M. Postan and E.E. Rich (eds), The Cambridge Economic History of Europe, Volume II, Cambridge, UK: Cambridge University Press, pp. 429-92.

Newton, L. (2007), 'Change and continuity: the development of joint stock banking in the early nineteenth century', University of Reading Business School Discussion Papers, Economics and Management Series, No 40.

Officer, L.H. (2002), 'The U.S. specie standard, 1792-1932: some monetarist arithmetic', Explorations in Economic History, 39, 113-53.

Perkins, E.J. (1994), American Public Finance and Financial Services 1700-1815, Columbus, OH, USA: Ohio State University Press. 
Pressnell, L.S. (1953), 'Public monies and the development of English banking', Economic History Review, 5 (3), 378-97.

Pressnell, L.S. (1956), Country Banking in the Industrial Revolution, Oxford: Clarendon Press.

Quinn, S. (1995), 'Balances and goldsmith-bankers: the co-ordination and control of inter-banker debt clearing in seventeenth-century London', in D. Mitchell (ed.), Goldsmiths, Silversmiths and Bankers, London: A. Sutton Publishing and Centre for Metropolitan History, pp. 53-76.

Redish, A. (1993), 'Anchors aweigh: the transition from commodity money to fiat money in western economies', Canadian Journal of Economics, 26 (4), 777-95.

Redish, A. (2000), Bimetallism: An Economic and Historical Analysis, Cambridge, UK: Cambridge University Press.

Rochon, L.-P. and S. Rossi (2013), 'Endogenous money: the evolutionary versus revolutionary views', Review of Keynesian Economics, 1 (2), 210-29.

Rousseau, P. (2006), 'A common currency: early US monetary policy and the transition to the dollar', Financial History Review, 13 (1), 97-122.

Rutner, J.L. (1974), 'Money in the antebellum economy: its composition, relation to income and its determinants', University of Chicago, $\mathrm{PhD}$ thesis.

Sargent, T.J. and F.R. Velde (2002), The Big Problem of Small Change, Princeton, NJ, USA: Princeton University Press.

Saville, R. (1996), The Bank of Scotland: A History 1695-1995, Edinburgh: Edinburgh University Press.

Smith, W.B. (1953), Economic Aspects of The Second Bank of the United States, Cambridge, MA, USA: Harvard University Press.

Smithin, J. (2003), Controversies in Monetary Economics, Cheltenham, UK and Northampton, MA, USA: Edward Elgar.

Spufford, P. (1970), Monetary Problems and Policies in the Burgundian Netherlands, 1433-1496, Leiden, Netherlands: E.J. Brill.

Spufford, P. (1988), Money and its Use in Medieval Europe, Cambridge, UK: Cambridge University Press.

Supple, B.E. (1957), 'Currency and commerce in the early seventeenth century', Economic History Review, 10 (2), 239-55.

Sylla, R. (1998), 'U.S. securities markets and the banking system, 1790-1840', Federal Reserve Bank of St. Louis Review, 80 (3), 83-98.

Timberlake, R. (1961), 'The specie standard and central banking in the United States before 1860', Journal of Economic History, 21 (3), 318-41.

Van der Wee, H. (1977), 'Monetary, credit and banking systems', in E.E. Rich and C.H. Wilson (eds), The Cambridge Economic History of Europe, Volume V, Cambridge, UK: Cambridge University Press, pp. 290-392.

Van der Wee, H. (1997), 'Banking and the rise of capitalism', in A. Teichova, G. Kurgan-Van Hentenryk and D. Ziegler (eds), Banking, Trade, and Industry: Europe, America and Asia from the Thirteenth to the Twentieth Century, Cambridge, UK: Cambridge University Press, pp. 173-88.

White, L. (1984), Free Banking in Britain: Theory, Experience, and Debate, 18001845, Cambridge, UK: Cambridge University Press.

White, L.H. (1991), 'Banking without a central bank: Scotland before 1844 as a "free banking" system', in F. Capie and G.E. Wood (eds), Unregulated Banking: Chaos or Order?, New York: St. Martin's Press, pp. 37-62.

Wray, L.R. (1993), 'The origins of money and the development of the modern financial system', Levy Economics Institute Working Paper, No 86. 